\title{
A CLINICAL STUDY OF SUBACUTE BACTERIAL INFECTION CONFINED TO THE RIGHT SIDE OF THE HEART OR THE PULMONARY ARTERY
}

\author{
Paul S. Barker, M.D. \\ AnN ARBor, Mich.
}

\begin{abstract}
GUBACUTE bacterial endocarditis involves the left side of the heart in nearly all cases. The complete descriptions of the disease by Libman and Friedberg, ${ }^{1}$ Blumer, ${ }^{2}$ and Middleton and Burke ${ }^{3}$ refer chiefly to this common type. The vegetations are confined to the right side of the heart in less than 4 per cent of the cases. ${ }^{4,5}$ In patent ductus arteriosus complicated by subacute bacterial endarteritis the vegetations are sometimes confined to the ductus, pulmonary artery, and pulmonic valves. Although some of the features of the right-sided type of the disease have been pointed out, notably by Gordon, ${ }^{6}$ Libman and Friedberg, ${ }^{1}$ Lutembacher, ${ }^{7.8}$ and Blumgart, ${ }^{9}$ it has not been described adequately. The purpose of this paper is to present a review of the clinical findings in cases proved by autopsy to have vegetations confined to the right side of the heart or the pulmonary artery.
\end{abstract}

\section{MATERIAL}

A search of the literature revealed thirty-six cases in which the data were sufficiently complete for the purposes of this study. To these are added five additional cases observed at the University Hospital, bringing the total to forty-one cases. Other cases have been reported in the literature, but are not included because the descriptions, particularly from the clinical standpoint, are not sufficiently complete. Similarly, the cases of patients with patent ductus arteriosus with superimposed subacute bacterial infection who recovered following ligation or section of the ductus are not included; although the infection was presumably limited to the right side in most if not all of them, this could not be determined with certainty. Cases of acute bacterial endocarditis are not included. ${ }^{10}$ Some of the reports deal with particular features of the disease and are incomplete in many respects, but in spite of this it is hoped that this report will present an adequate clinical description of the right-sided type of subacute bacterial endocarditis.

\footnotetext{
From the Department of Internal Medicine, University of Michigan Medical School and the University Hospital.

Presented at the Twenty-First Scientific Meeting of the American Heart Assoclation, Chicago, Ill., June 18, 1948.
} 


\section{REPORT OF CASES}

CASE 1.-V. S., a 13-year-old white boy, was admitted to the hospital Feh. 6, 1939, and died Feb. 12, 1939. At the age of 3 weeks the patient bad a severe cough and the parents were told that it was caused by heart disease. At 3 months of age he became extremely ill with high fever and was kept in the hospital for eight months. At 3 years of age he developed hay fever, which was accompanied by cough and which was worse in summer. In January, 1938, he began having chills and fever. He was somewhat improved after twelve weeks, but low-grade fever persisted. In October, 1938, the chills recurred and the fever became higher. On Jan. 23, 1939, he devaloped swelling of the left eyelids. On Feb. 5, 1939, he developed swelling of the left foot and gangrene of the pinnae of the ears and tip of the nose. Numerous small red spots apperared in the skin. He had anorexia, nausea, and vomiting. There was no history of rheunatic fever.

Physical examination revealed a pale, emaciated boy with a temperature of $102^{\circ} \mathrm{F}$., pulse rate of 132 , and respiratory rate of 30 . There were small areas of ulceration on the pinnae of the: ears and tip of the nose. Numerous petechiae were present on the trunk and extremities. The heart was moderately enlarged and the rhythm regular. There was a loud systolic murmur over the entire precordium and a questionable diastolic murmur in the aortic area. The lungs were resonant and there were no râles, but the breath sounds were diminished at the bases. Thi' spleen was enlarged and palpable; the liver was not felt. There was no edema.

Laboratory examinations revealed the following findings: The urine contained a moderate: amount of albumin and a few red cells, white cells, and casts. The blood revealed a hemoglobin of 20 per cent, a red blood cell count of $1,620,000$, and a white blood cell count of 7,000 , with 74 per cent polymorphonuclear leucocytes. The blood culture was posilive for Streptococcus viridans.

The course was progressively downward in spite of small blood transfusions daily.

Necropsy showed congenital heart disease with a large defect in the interventricular septum and hypertrophy of the right ventricle. There was subacute bacterial endocarditis with vegetations on the tricuspid and pulmonic valves, on the mural endocardium of the right ventricle, and on the margin of the septal defect. There were no vegetations in the left side of the heart. There were infected pulmonary emboli and pulmonary infarcts, acute pulmonary edema, acute purulent bronchitis, acute fibrinopurulent lobular pneumonia, and bronchiectasis. There were healed and healing infected infarcts of the spleen, which weighed 400 grams, and recent healing and healed embolic glomeruiitis.

CASE 2.-W. W., a 25-year-old white man, was admitted to the hospital Nov. 9, 1926, anil died Dec. 17, 1926. Dyspnea and palpitation occurred upon exertion during childhood and heart disease was recognized. Nevertheless, he was accepted for life insurance at the age of 17 years. In November, 1925, he developed dyspnea upon exertion and fatigue and began losing weight. In February, 1926, he developed increasing dyspnea and palpitation and stopped work. In April, 1926, he developed cough productive of a little sputum, but no blood. Edema of the ankles: appeared in May, 1926. There was no known fever and no history of rheumatic fever or venereal disease.

The physical examination revealed a thin, pale, slightly cyanotic young man with clubbin: of the fingers but no petechiae. The heart was enlarged and the rhythm regular. There was a loud, harsh systolic murmur accompanied by a thrill in the second intercostal space to the lef: and right of the sternum and a softer systolic murmur at the apex, but no diastolic murmur. The? blood pressure was 106/54. The lungs were clear, the spleen was palpable, and there was slight edena of the ankles.

Laboratory examinations revealed a negative Wassermann. The urine showed a trace of albumin, moderate numbers of red cells, and a few white cells. The blood revealed a hemoglobin of 60 per cent, a red blood cell count of $3,310,000$, and a white blood cell count of 16,200, with 91 per cent polymorphonuclear leucocytes. X-ray films of the chest showed enlargement of the heart and densities in the lungs suggesting infarcts or bronchopneumonia. The electrocardiogram showed right axis deviation. Blood cultures were positive for Streptococcus viridans. 
The course was progressively downward. The temperature fluctuated from 97 to $102^{\circ}$ Fahrenheit. Râles and bronchovesicular breath sounds appeared over the right lung. No petechiae or systemic emboli were recognized.

Necropsy showed congenital pulmonary stenosis and subacute bacterial endocarditis with vegetations on the pulmonic and tricuspid valves. There were vegetations and an early mycotic aneurysm in the first part of the pulmonary artery. There were no vegetations or valve lesions in the left side of the heart and no abnormal communication. There were multiple large infarcts of the lungs and multiple small infarcts of the kidneys. There was hyperplasia of the spleen, which weighed 230 grams, but no infarcts.

CASE 3.- N. B., a 48-year-old East Indian man, was admitted to the hospital Jan. 19, 1938, and died March 15, 1938. The history revealed that for four months the patient had experienced chills, fever, sweats, cough, bloody sputum, pains in the chest and left shoulder, anorexia, and loss of fifty pounds in weight,

Physical examination revealed a pale, emaciated, and dyspneic man with slight cyanosis and clubbing of the fingers, but no petechiae. The heart was slightly enlarged, the rhythm was regular, and no murmurs were detected. The blood pressure was $85 / 50$. There were a few râles at the lung bases. The liver and spleen were not felt. There was no edema.

Laboratory examinations revealed the following findings: The Kahn reaction of the blood was negative. The urine showed a large amount of albumin and a few red cells and white cells. The blood revealed a hemoglobin of 55 per cent, a red blood cell count of $2,380,000$, and a white blood cell count of 16,500 , with 81 per cent polymorphonuclear leucocytes. X-ray study of the chest showed slight enlargement of the heart, but no abnormality of the lungs. The electrocardiogram showed slight left axis deviation. The total serum proteins were 4.5 per cent, albumin 1.6 per cent, and globulin 2.9 per cent. The blood nonprotein nitrogen was $68.1 \mathrm{mg}$. per cent. Blood cultures were sterile on four occasions.

The course was progressively downward, apparently without change in physical signs. The temperature fluctuated between $94^{\circ}$ and $106^{\circ}$ Fahrenheit. Sulfanilamide and four blood transfusions were given.

Necropsy showed ulcerative and vegetative endocarditis of the pulmonary valve and of the walls of the right ventricle and pulmonary artery. The other valves and the left side of the heart were not involved and there were no abnormal communications. There was a large infected embolus in the left pulmonary artery and infarction of the lower lobe of the left lung. There was chronic passive congestion of the spleen. Chronic glomerulonephritis was present. No systemic emboli were discovered.

CASE 4.-M. B., a 3-year-old white girl, was admitted to the hospital Oct. 14, 1932, and died Nov. 11, 1932. The patient was thought to have congenital heart disease since a cardiac murmur had been present since infancy. For four weeks prior to admission the child had a cold, a sore throat, chills, fever, cough, and constipation.

Physical examination showed a well-developed and well-nourished child with pallor but no petechiae and no clubbing of the fingers. The heart was enlarged and there was a systolic murmur heard over the entire precordium and loudest at the apex. The lungs were clear. The liver and spleen were not felt. There was no edema.

Laboratory examinations revealed a negative Kahn reaction of the blood. The urine showed a few white cells but was otherwise negative. Blood studies revealed a hemoglobin of 66 per cent, a red blood cell count of 4,480,000, and a white blood cell count of 21,000 with 77 per cent polymorphonuclear cells. X-ray study of the chest was negative. Blood cultures were reported as follows: October 14, no growth; October 29, slight growth of hemolytic streptococcus; October 31, no growth; and November 7, Staphylococcus aureus and a nonhemolytic streptococcus.

The course was progressively downward. The temperature ranged from $101^{\circ}$ to $105^{\circ}$ Fahrenheit. Râles appeared in the lungs and the spleen became enlarged, but no petechiae or systemic emboli were seen.

Necropsy showed subacute bacterial endocarditis with vegetations on the pulmonary valve and on the wall of the right ventricle. The other valves and the left ventricle were not involved 
and there were no abnormal communications. There were infected infarcts and early embolic abscesses of the lungs. There was hyperplasia and passive congestion of the spleen. No srstemic embolism was discovered.

CASE 5.-D. C., a 29-year-old white woman, was admitted to the hospital Sept. 15, 1932, and died Oct. 2, 1932. For eight weeks prior to admission the patient had chills, fever, pains in the joints and muscles, anorexia, nausea, vomiting, cough, weakness, and a loss of eighteen pounds in weight.

Physical examination revealed an obese, pale woman with alopecia, but no petechiae or clubbing of the fingers. There was a soft systolic murmur over the entire precordium. No other murmur was heard and there was no enlargement of the heart. The blood pressure was 120/80. The lungs were clear. The liver and spleen were enlarged and palpable. There was no edema.

Laboratory examinations showed that the Kahn reaction of the blood was 4 plus. The urine showed a few red cells and white cells but was otherwise negative. Blood studies revealed a hemoglobin content of 68 per cent, a red blood cell count of 4,040,000, and a white blood cell count of 15,500 , with 88 per cent polymorphonuclear leucocytes. X-ray study of the chest showed no abnormality of the heart or lungs. Blood cultures were sterile on two occasions.

The course was progressively downward. The temperature ranged from $97^{\circ} \mathrm{F}$. to $105^{\circ}$ Fahrenheit.

Necropsy showed subacute bacterial endocarditis of the tricuspid valve. The other valves and the left ventricle were not involved and there were no abnormal communications. There were passive congestion of the lungs and liver, hyperplasia of the spleen, which weighed $470 \mathrm{grams}$, and chronic glomerulonephritis. There was no evidence of embolism, gonorrhea, or syphilis.

Of the forty-one cases accepted for this study, nine had patent ductus arteriosus, eleven had interventricular septum defect, one had interauricular septum defect, fifteen had vegetations limited chiefly to the pulmonic valve without abnormal communications, and five had vegetations limited chiefly to the tricuspid valve without abnormal communications. The ages of the patients ranged from 3 to 58 years, and the average was 20.6 years. There were eighteen males and twenty-three females. The important features of these cases are presented in the accompanying Tables I-V and are compared or con-. trasted with the common left-sided type of the disease.

\section{CLINICAL OBSERVATIONS}

Murmurs were present in thirty-scven of the cases. In four paticnts no murmurs were heard. Two of these had vegetations confined chiefly to the pulmonic valve, while in the third they were confined to the tricuspid valve; in the remaining patient a pericardial friction rub was present and no murmur was identified. Thus, 90 per cent of the patients had cardiac murmurs. In seven cases, however, there were systolic murmurs at the apex or base of the heart or over the precordium, such as are commonly heard in patients with fever and anemia, and were not, therefore, suggestive of a cardiac lesion. In the remaining thirty patients, 73 per cent of the entire group, the murmurs were harsh or were accompanied by a thrill or were diastolic in time, and were thought to indicate a cardiac lesion (Table $V$ ).

Fever was present in forty cases. In the remaining case the report did not mention the temperature. 


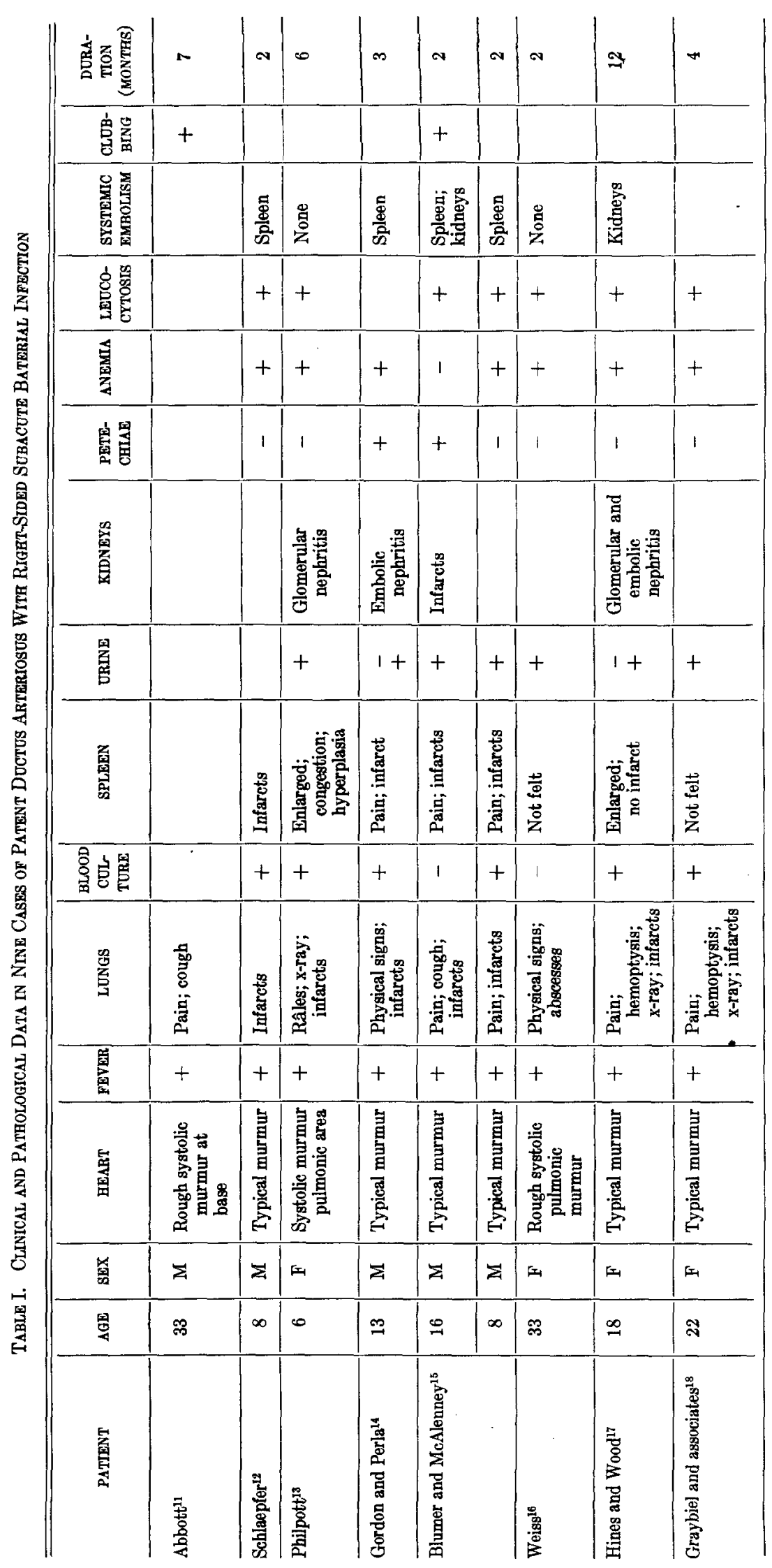




\begin{tabular}{|c|c|c|c|c|c|c|c|c|c|c|}
\hline 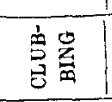 & + & & & & & & & & & \\
\hline 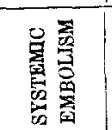 & 1 & & 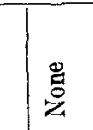 & & $\frac{12}{2}$ & 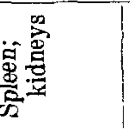 & $\frac{1}{12}$ & & 基 & I \\
\hline 讋爵 & & & & & + & & + & $1+$ & $1+1+$ & \\
\hline 咅 & + & & $1+$ & & 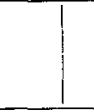 & & + & + & $1+1$ & + \\
\hline 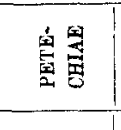 & & & & & + & + & + & & , & + \\
\hline 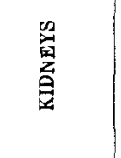 & 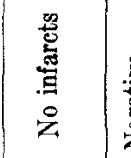 & 量哀言 & & & & 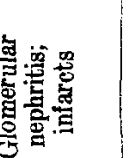 & 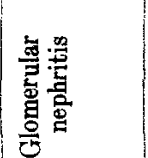 & 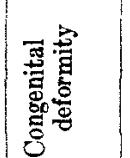 & & 竞 \\
\hline 岦 & $1+1$ & & ' & +1 & & $1+$ & + & & +1 & ++ \\
\hline 垴 & 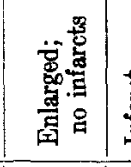 & & 童 & & & $\frac{1}{19}$ & 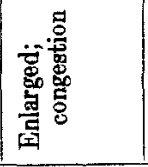 & & & 鄫 \\
\hline 䇾軆| & & 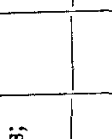 & & & ' & $1+$ & 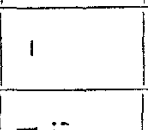 & $1+$ & $1+1+$ & $1+$ \\
\hline$\frac{1}{3}$ & 量詈 & 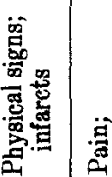 & & & & 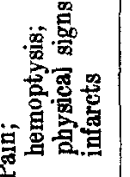 & 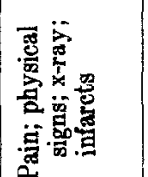 & 离部 & & 量 \\
\hline 1 & $1+1$ & & & & & + & + & & & It \\
\hline 亲 & 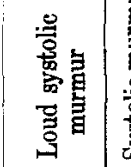 & & 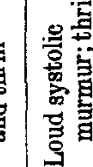 & & & 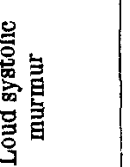 & & 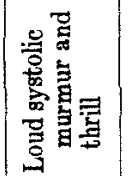 & & 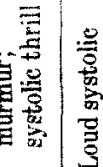 \\
\hline 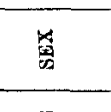 & $-1=$ & $=1 z$ & $\equiv$ & & $=1$. & 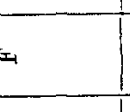 & $\omega$ & $\infty$ & -18 & $=$ \\
\hline$\frac{g}{2}$ & $\because$ & $-1 \bar{c}$ & 10 & & 6 & 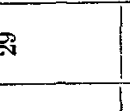 & 9 & $\approx$ & 8 & $=$ \\
\hline 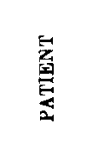 & & & & & & & & & & \\
\hline
\end{tabular}




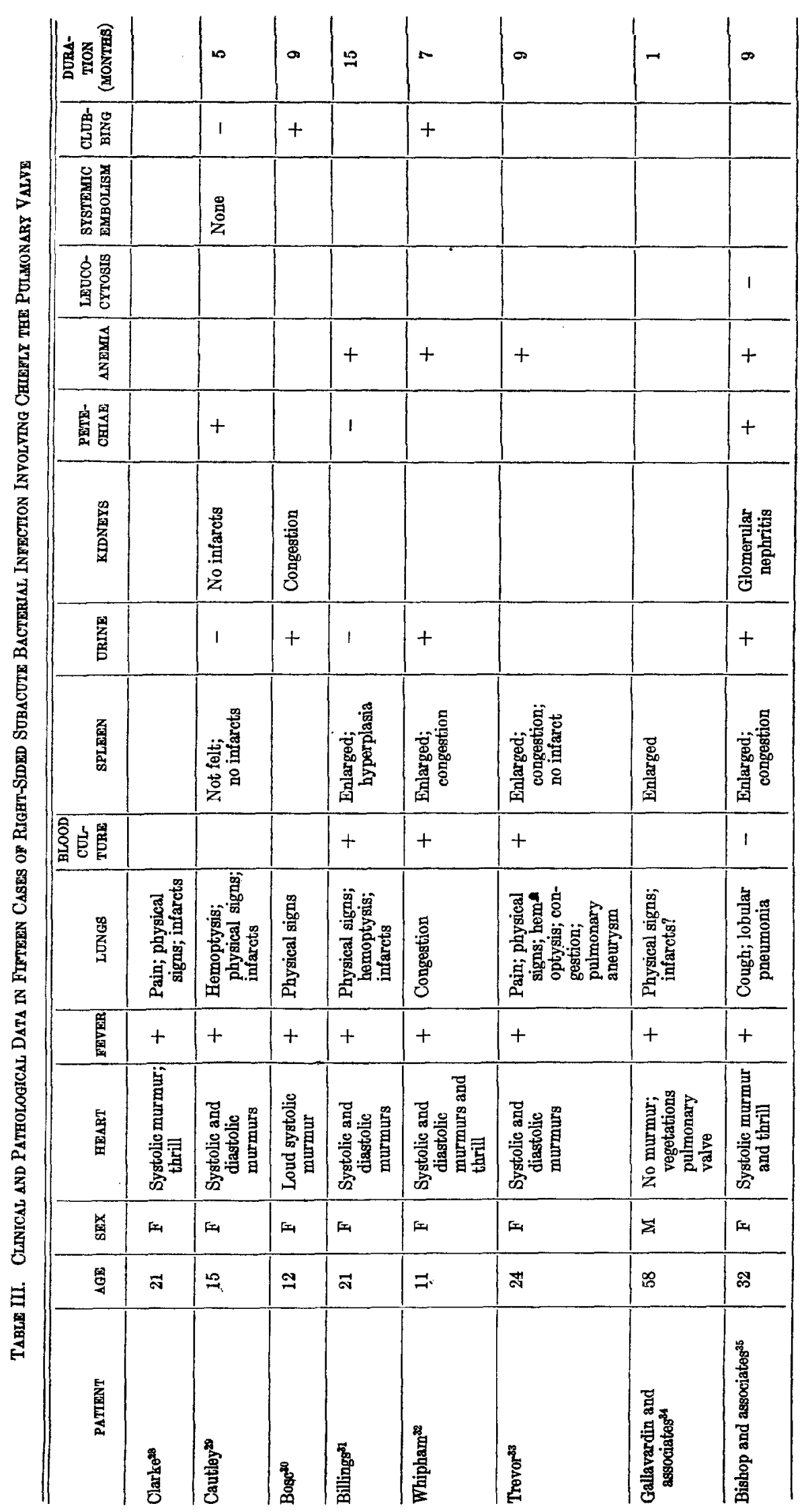


In thirty-three of the cases, clinical findings referable to the lungs were mentioned. In twenty-seven of these ( 82 per cent) the findings were suggestive or diagnostic of infarction of the lungs. In thirty-six of the cases the findings in the lungs at autopsy are given; thirty of these ( 83 per cent) showed infarcts of the lungs. Mycotic aneurysms of the pulmonary artery were present in five of these cases.

In twenty-one instances reference was made to the clinical occurrence or absence of embolism of the systemic circulation; it was suspected clinically in only four patients (19 per cent). One of these had swelling of the left foot and of the lids of the left eye and gangrene of the pinnae of the ears and tip of the nose; these regions were not dissected at autopsy, but infarction of the spleen and embolic focal nephritis were found. A second patient had ptosis of the eyelid on the left and embolism was suspected, but the only indication of embolism at autopsy was an old scar in the spleen. A third patient, with enlargement and tenderness of the spleen, had sudden, severe pain in the left hypochondrium; infarction of the spleen was diagnosed clinically and confirmed at autopsy. These three patients had interventricular septal defect. The fourth patient with patent ductus arteriosus had pain in the left upper quadrant of the abdomen, which suggested infarction of the spleen; this was confirmed at autopsy. In twenty-eight cases the presence or absence at autopsy of embolism in the systemic circulation was mentioned. It was present in twelve instances ( 43 per cent), and ten of these patients had septal defect or patent ductus arteriosus.

Blood cultures were reported in twenty-nine instances. They were positive in eighteen cases (62 per cent) and sterile in eleven cases ( 38 per cent).

Enlargement of the spleen was detected in twenty-one (78 per cent) of the twenty-seven cases in which this physical finding was mentioned. In fifteen of these no infarction of the spleen was found at autopsy. At autopsy, infarction of the spleen was reported in nine cases; infarction, passive congestion, and hyperplasia, in one case; congestion and hyperplasia, in two cases; hyperplasia, in four cases; and congestion, in seven cases. In eighteen cases the appearance of the spleen at autopsy was not adequately described, although in a few of these the absence of infarcts was noted.

The urine was abnormal in twenty-seven cases, not abnormal in four cases, and not mentioned in ten cases. Thus, the urine was abnormal in 87 per cent of the cases in which it was mentioned. In five patients the urine was normal early in the course of the disease but became abnormal later.

The condition of the kidneys at autopsy was reported in twenty-three instances. In nine of these (39 per cent) glomerulonephritis was present; in three cases (13 per cent) there was embolic focal nephritis, and in a similar number infarcts were present; in four cases (17 per cent) there was congestion; and in one patient tuberculosis of the kidneys was present.

Petechiae were present in eleven cases, absent in twelve, and not mentioned in eighteen. Thus, petechiae were present in 48 per cent of the cases in which this feature was mentioned specifically. Three patients had purpura. Janeway lesions and Osler's nodes were not described in any of the cases. 


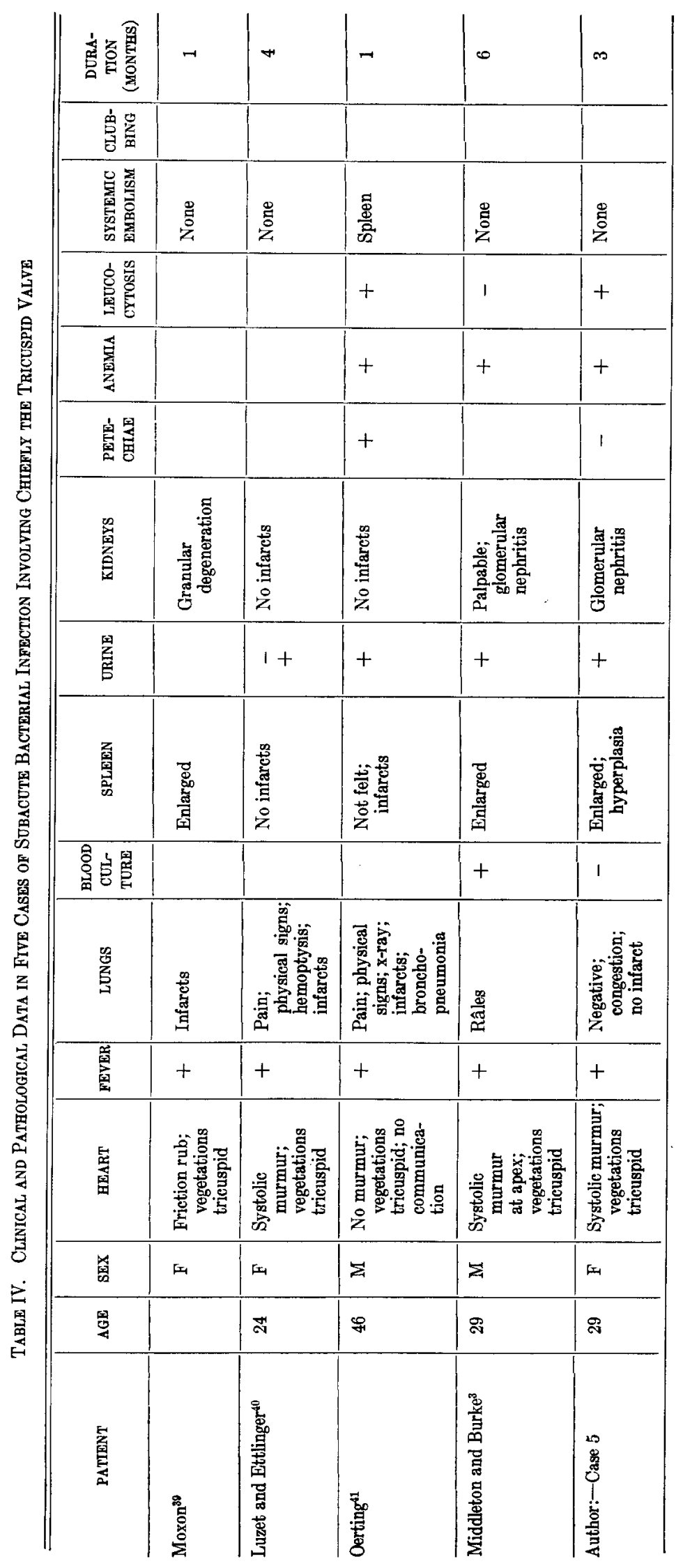




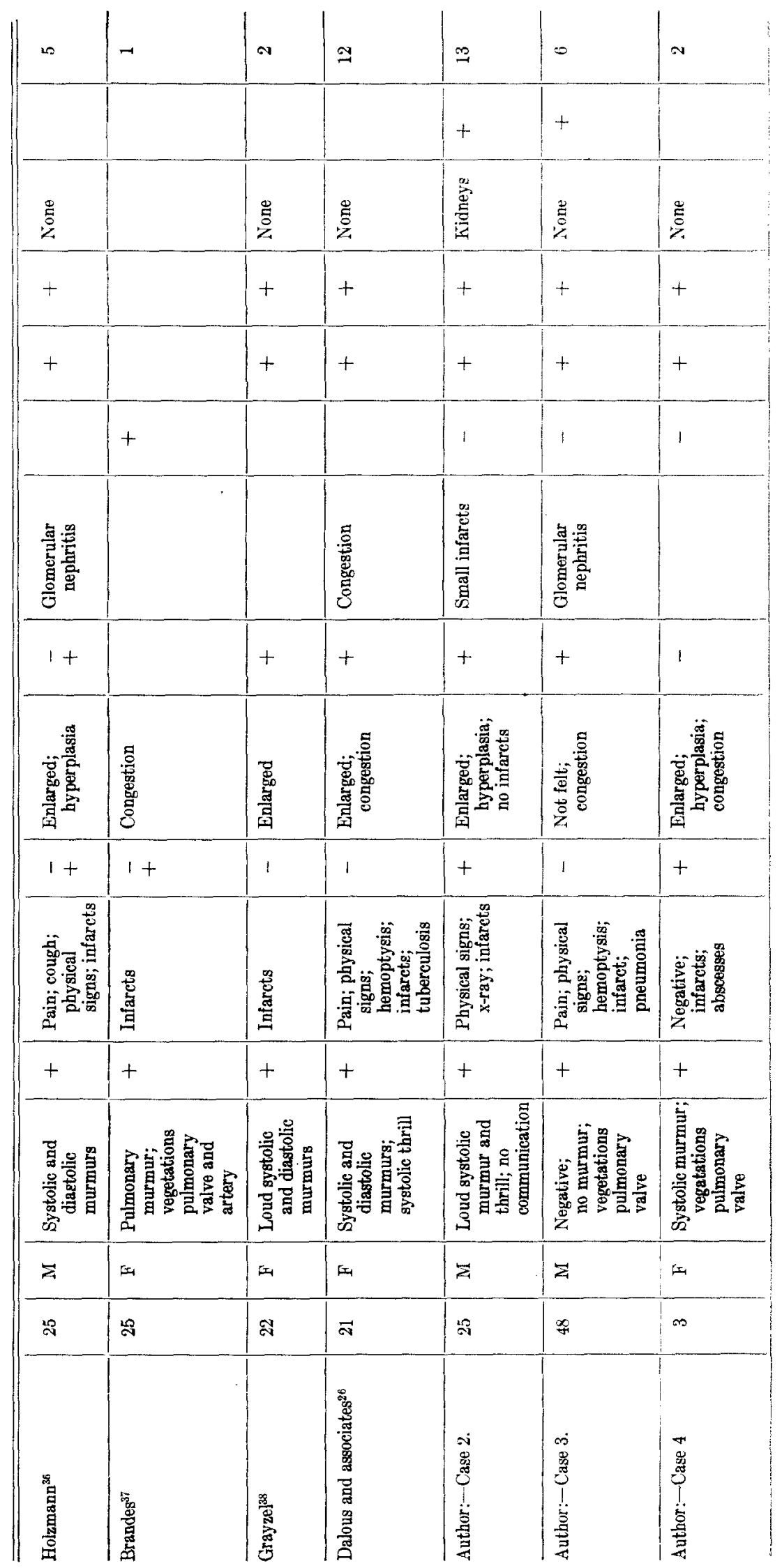


Tabli V. Summary of Clinical Data in Forty-ong Cases of Subacute Bacterial Infaction of the Right Side of the Heart and OF THe Pulmonary ARTERY; Comparison With INYolvemgant of the LEFT Side OF THE HeART*

\begin{tabular}{|c|c|c|c|c|c|c|}
\hline & $\begin{array}{l}\text { PATTENT } \\
\text { DUCTUS }\end{array}$ & $\begin{array}{l}\text { SEPTUM } \\
\text { DEFECT }\end{array}$ & $\begin{array}{l}\text { PULMONARY } \\
\text { VALVE }\end{array}$ & $\begin{array}{l}\text { TRICUSPID } \\
\text { VALVE }\end{array}$ & $\begin{array}{c}\text { TOTAL } \\
\text { RIGHT-SIDED } \\
\text { CASES }\end{array}$ & $\begin{array}{l}\text { LEFT-SIDED } \\
\text { CASES }\end{array}$ \\
\hline No. of Cases & 9 & 12 & 15 & 5 & 41 & \\
\hline $\begin{array}{l}\text { Age, years } \\
\text { Averago }\end{array}$ & $\begin{array}{l}6 \text { to } 33 \\
17\end{array}$ & $\begin{array}{c}4 \text { to } 29 \\
15\end{array}$ & $\begin{array}{c}3 \text { to } 58 \\
24\end{array}$ & $\begin{array}{c}24 \text { to } 46 \\
32\end{array}$ & $\begin{array}{c}3 \text { to } 58 \\
20.6\end{array}$ & 4 to 74 \\
\hline $\begin{array}{l}\text { Sex } \\
\text { Male } \\
\text { Femalo }\end{array}$ & $\begin{array}{l}5 \\
4\end{array}$ & $\begin{array}{l}7 \\
5\end{array}$ & $\begin{array}{r}4 \\
11\end{array}$ & $\begin{array}{l}2 \\
3\end{array}$ & $\begin{array}{l}18 \\
23\end{array}$ & $\underset{\text { predominate }}{\text { males }}$ \\
\hline $\begin{array}{l}\text { Murmurs } \\
\text { Pathologic murmurs } \\
\text { No murmur }\end{array}$ & $\begin{array}{l}9 \\
8 \\
0\end{array}$ & $\begin{array}{r}12 \\
11 \\
0\end{array}$ & $\begin{array}{r}13 \\
11 \\
2\end{array}$ & $\begin{array}{l}3 \\
0 \\
2\end{array}$ & $\begin{array}{rr}37 & 90 \% \\
30 & 73 \% \\
4 & 10 \%\end{array}$ & $99.2 \%$ \\
\hline Fever & 9 & 11 & 15 & 5 & $40 \quad 100 \%$ & $100 \%$ \\
\hline $\begin{array}{l}\text { Infarcts, lungs } \\
\text { Clinical } \\
\text { Autopsy }\end{array}$ & $\begin{array}{l}6 \\
7\end{array}$ & $\begin{array}{l}9 \\
9\end{array}$ & $\begin{array}{l}10 \\
11\end{array}$ & $\begin{array}{l}2 \\
3\end{array}$ & $\begin{array}{l}82 \% \\
83 \%\end{array}$ & $\begin{array}{c}57 \quad \% \\
\text { (systemic) }\end{array}$ \\
\hline Blood culture & 6 & 5 & 6 & 1 & $18 \quad 62 \%$ & $78.8 \%$ \\
\hline $\begin{array}{l}\text { Spleen } \\
\text { Clinically enlarged } \\
\text { Autopay infarct } \\
\text { Congegtion } \\
\text { Hyperplasia }\end{array}$ & $\begin{array}{l}2 \\
4 \\
1 \\
1\end{array}$ & $\begin{array}{l}8 \\
5 \\
2 \\
1\end{array}$ & $\begin{array}{l}9 \\
0 \\
7 \\
4\end{array}$ & $\begin{array}{l}2 \\
1 \\
0 \\
1\end{array}$ & $\begin{array}{r}21 \\
10 \\
10 \\
7\end{array}$ & $59 \%$ \\
\hline Urine abnormal & 7 & 8 & 8 & 4 & $27 \quad 87 \%$ & $61.6 \%$ \\
\hline $\begin{array}{l}\text { Kidneys, autopsy } \\
\text { Glomerular nephritis } \\
\text { Embolic nephritis } \\
\text { Infarcts }\end{array}$ & $\begin{array}{l}2 \\
2 \\
1\end{array}$ & $\begin{array}{l}2 \\
1 \\
1\end{array}$ & $\begin{array}{l}3 \\
0 \\
1\end{array}$ & $\begin{array}{l}2 \\
0 \\
0\end{array}$ & $\begin{array}{l}9 \\
3 \\
3\end{array}$ & \\
\hline Petechiao & 2 & 5 & 3 & 1 & $11 \quad 48 \%$ & $86.5 \%$ \\
\hline Anemia & 7 & 8 & 10 & 3 & $28 \quad 97 \%$ & $70 \%$ \\
\hline Leucocytosis & 7 & 5 & 6 & 2 & $20 \quad 87 \%$ & $43.5 \%$ \\
\hline $\begin{array}{l}\text { Systomic } \\
\text { Embolism } \\
\text { Autopsy }\end{array}$ & 5 & 5 & 1 & 1 & $12 \quad 43 \%$ & $\begin{array}{c}57 \% \\
\text { (clinical) }\end{array}$ \\
\hline Clubbing & 2 & 2 & 4 & 0 & 8 & $46.7 \%$ \\
\hline $\begin{array}{c}\text { Duration, months } \\
\text { Average }\end{array}$ & $\begin{array}{c}2 \text { to } 12 \\
4.4\end{array}$ & $\begin{array}{l}1 \text { to } 13 \\
6.8\end{array}$ & $\begin{array}{l}1 \text { to } 15 \\
6.9\end{array}$ & $\begin{array}{c}1 \text { to } 6 \\
3\end{array}$ & $\begin{array}{c}1 \text { to } 15 \\
5.8\end{array}$ & $\begin{array}{c}2 \text { to } 19 \\
5.9\end{array}$ \\
\hline
\end{tabular}

Whe percentages given for the right-sided cases represent the percentage of cases in which the various data are reported. Many of the reports are incomplete. The figures for the left-sided cases are aken from several sources, sometimes combined. 
Clubbing of the fingers was noted in eight patients, all of whom had vegetations on the pulmonic valve. Two of these had patent ductus arteriosus and one had, in addition, interventricular septal defect. In most of the remaining thirty-three cases clubbing was not mentioned.

Anemia, as shown by pallor, by a hemoglobin level below 78 per cent, or by a red blood cell count below 4,000,000, was present in twenty-eight ( 97 per cent) of the twenty-nine cases in which this feature was mentioned. Leucocytosis, with the total white blood cell count above 10,000, was present in twenty ( 87 per cent) of the twenty-three cases in which the leucocyte count was given.

The blood pressure was recorded in twelve patients. It was not elevated in a single instance.

The estimated duration of the subacute bacterial infection was one to fifteen months, with an average of 5.8 months.

\section{DISCUSSION}

Subactute bacterial infection confined to the right side of the heart is mainly a disease of childhood and youth. This may be attributed to the fact that it is often a complication of congenital cardiac conditions since twenty. five of the cases ( 61 per cent) had congenital anomalies. Almost two-thirds of the patients with patent ductus arteriosus or interventricular septum defect were younger than twenty-one years of age.

The four cardinal diagnostic features of subacute bacterial endocarditis which were emphasized by Osler ${ }^{42}$ and reiterated by Blumer ${ }^{2}$ and by Libman and Friedberg ${ }^{1}$ were present in these right-sided cases as follows: (1) evidence of a valvular lesion or of a congenital abnormality, in 73 per cent; (2) fever, in 100 per cent; (3) embolic phenomena, in 82 per cent; and (4) a positive blood culture, in 62 per cent. Information is lacking in some of the reports, but the data are adequate in a sufficient number of cases to permit the following conclusions: (1) All four of these diagnostic features were present in twelve instances (39 per cent) and at least one of these features was lacking in nineteen instances ( 61 per cent) of the thirty-one cases with adequate available information for this purpose; and (2) at least three of these four features were present in twenty-eight instances ( 82 per cent) of the thirty-four cases with sufficiently complete data for this purpose. These appear to be the most important diagnostic features when the vegetations are confined to the right side as well as when the left side is involved. Nevertheless, some of the other features of the disease may assume considerable diagnostic importance, especially when not all of the cardinal features are present.

It is important to note that the clinical manifestations of embolism were produced chiefly by infarction of the lungs ${ }^{6}$ and that signs of systemic embolism were much less common. It is of interest, however, that systemic embolism was discovered at autopsy in two patients with vegetations confined to the right side of the heart and without any abnormal communication between the 
right and left sides. In one, the vegetations were confined to the tricuspid valve and several well-defined areas of infarction were present in the spleen. In the other, the vegetations were chiefly on the pulmonic and tricuspid valves and there were multiple small infarcts in the kidneys. Both of these patients had extensive infarction of the lungs, and the possibility of thrombosis of pulmonary veins in association with infarction of the lungs is suggested as a source of the systemic emboli.

Blumgart ${ }^{9}$ has pointed out that in cases with the infection limited to the right side of the heart, the blood cultures are commonly sterile early in the disease, although they may become positive later. Blood cultures were reported in twenty-nine of the cases in this series. They were positive in fourteen and negative in eleven, while in four they were negative one to three months after the estimated onset of the disease and positive later in its course. The fourteen initially positive cultures were obtained from ten days to fourteen months after the estimated onset of the disease. In the eleven patients who yielded no growth the cultures were obtained from one to eight months after the estimated onset of the disease. Thus, it appears that not only is there a delay in some cases in yielding positive cultures, but many patients have sterile cultures throughout the course of the disease. As a result, one of the cardinal diagnostic features of the disease is lacking in approximately one-half of those patients examined early in the course of the disease.

Differential diagnosis may be difficult when the blood cultures are sterile. For example, a youth of 21 years had a systolic murmur at the apex of the heart, fever, anemia, leucocytosis, and pronounced enlargement of the spleen; he was thought at first to have the abdominal type of Hodgkin's disease, but the subsequent appearance of petechiae and positive blood cultures led to the diagnosis of the splenomegalic form of subacute bacterial endocarditis. In the presence of a cardiac murmur, conditions characterized by pulmonary lesions and fever may resemble right-sided subacute bacterial endocarditis in many respects, especially if the spleen is enlarged and if anemia and leucocytosis are present. For example, a 40-year-old woman had repeated infarction of the lungs, persistent low-grade fever, leucocytosis, and a systolic murmur over the precordium, and, although repeated blood cultures were sterile, the diagnosis of rightsided subacute bacterial endocarditis was entertained. Later, however, the presence of phlebothrombosis in the lower extremities became apparent, and treatment for this condition was followed by complete recovery.

The four cardinal diagnostic features, when present, will point most surely to the presence of subacute bacterial endocarditis. Nevertheless, some of these features may be lacking in cases with right-sided involvement, especially early in the course of the infection when the blood cultures are so commonly sterile. For this reason, greater diagnostic significance may be attached to the other features of the disease, such as enlargement of the spleen, petechiae, anemia, leucocytosis, and evidence of renal involvement.

The presence of vegetations in both the right and left sides of the heart is fairly common. This study has revealed $\mathrm{n} n$ criteria by means of which it 
can be ascertained clinically that the infection is confined to either the right side or the left side, but pulmonary embolism suggests vegetations on the right side whether or not the left side is involved.

\section{SUMMARY}

In less than 4 per cent of patients with subacute bacterial endocarditis, the vegetations are confined to the right side of the heart. In patients with patent ductus arteriosus with subacute bacterial endarteritis the infection may be confined to the ductus and the pulmonary artery.

A study of thirty-six such cases reported in the literature and five newly reported cases forms the basis for a description of the clinical features of subacute bacterial infection confined to the right side of the heart and the pulmonary artery.

The four cardinal diagnostic features of left-sided subacute bacterial endocarditis are of chief importance in the diagnosis of the right-sided type as well, but because the blood cultures are often sterile and embolism is sometimes absent or obscure, greater diagnostic significance may be attached to the other features of the disease.

\section{REFERENCES}

1. Libman, E., and Friedberg, C. K.: Subacute Bacterial Endocarditis, New York, 1941, Oxford University Press (Reprinted from Oxford Loose-Leaf Medicine).

2. Blumer, G.: Subacute Bacterial Endocarditis, Medicine 2:105, 1923.

3. Middleton, W. S., and Burke, M.: Streptococcus Viridans Endocarditis Lenta. A ClinicoPathological Analysis of the Experience in the Wisconsin General Hospital, Am. J. M. Sc. 198:301, 1939.

4. Osler, W.: Malignant Endocarditis, Lancet 1:415-418, 459-464, 505-508, 1885.

5. Washbourn, J. W.: A Discussion on the Pathology of Infective Endocarditis. I. Anatomy of the Endocardium, Brit. M. J. 2:1269, 1899.

6. Gordon, W.: Perforate Septum Ventriculorum With Infective Endocarditis of the Pulmonary Valves, Brit. M. J. 2:1174, 1897.

7. Lutembacher, R.: Endocardite subaguë et endartérite pulmonaire chez les cardiaques. Arch. d. mal. du. coeur 10:353, 1917.

8. Lutembacher, R.: Endocardite infectieuse secondaire des cardiaques, Presse méd. 26:546, 1918.

9. Blumgart, H. L.: The Clinical Syndrome of Subacute Bacterial Endocarditis Involving the Right Chambers of the Heart, M. Clin. North America 16:881, 1932-1933.

10. Libman, E.: Characteristics of Various Forms of Endocarditis, J. A. M. A. 80:813, 1923.

11. Abbott, M. E.: On the Incidence of Bacterial Inflammatory Processes in Cardiovascular Defects and on Malformed Semilunar Cusps, Ann. Clin. Med. 4:189, 1925.

12. Schlaepfer, K.: Chronic and Acute Arteritis of the Pulmonary Artery and of the Patent Ductus Arteriosus, Arch. Int. Med. 37:473, 1926.

13. Philpott, N. W.: Two Cases of Cardiovascular Anomaly. I. Vegetative Pulmonary Endarteritis Complicating Persistent Ductus. II. Hypoplasia of Aorta, Ann. Int. Med. 2:948, 1929.

14. Gordon, H., and Perla, D.: Subacute Bacterial Endarteritis of Pulmonary Artery Associated With Patent Ductus Arteriosus and Pulmonic Stenosis, Am. J. Dis. Child. 41:98, 1931 .

15. Blumer, G., and McAlenney, P.: The Relationship of Patent Ductus Arteriosus to Infectious Processes in the Duct Itself, in the Pulmonary Artery, the Aorta and the Heart Valves, Yale J. Biol. \& Med. 3:483, 1931.

16. Weiss, E.: Calcified Plaque of the Aorta at the Entrance of a Patent Ductus Arteriosus: A Point in Diagnosis, AM. HEART J. $7: 114,1931-1932$. 
17. Hines, D. C., and Wood, D. A.: Patent Ductus Arteriosus Complicated by Endocarditis and Hemorrhagic Nephritis, Am. HearT J. 10:974, 1935.

18. Graybiel, A., Strieder, J. W., and Boyer, N. H.: An Attempt to Obliterate the Patent Ductus Arteriosus in a Patient With Subacute Bacterial Endarteritis, AM. HEART J. $15: 621,1938$.

19. Mayer M.: Ueber einen Fall von Stenosirung der Pulmonalarterie in Folge von acuter Endocarditis der Semilunarklappen, Deutsches Arch. f. klin. Med. 24:435, 1879.

20. Tuckwell: A Case of Ulcerative Endocarditis in a Child, Affecting the Pulmonary Valves, With Certain Congenital Defects in the Heart; Necropsy; Remarks, Lancet 1:516, 1885.

21. Mackenzie, H. W. G.: Congenital Disease of the Heart With Right-sided Endocarditis, Tr. Path. Soc. London 41:58, 1890.

22. Horder, T. J.: Infective Endocarditis With an Analysis of 150 Cases and With Special Reference to the Chronic Form of the Disease, Quart. J. Med. 2:289, 1909.

23. Humphry, L.: Multiple Embolic Aneurysms of the Pulmonary Artery, J. Path. \& Bact. 17:212, 1912-1913.

24. Moschcowitz, E.: Vegetative Endocarditis of the Pulmonary Valve; Thrombosis of One of the Branches of the Right Pulmonary Artery; Embolus of the Left Pulmonary Artery; Patent Ventricular Septum, Proc. New York Path. Soc., N. S. 14:18, 1914.

25. Audibert, V., Raybaud, A., Giraud-Costa, E., and Audier, M.: Maladies congénitales du coeur et endocardite maligne a marche lente, Paris méd. 87:369, 1933.

26. Dalous, M. M., Roques, Fabre, J., and Pons, H.: Les endocardites malignes du coeur droit, Arch. d. mal. du coeur 32:945, 1939.

27. Eigen, L. A., and Abel, A. R.: Subacute Bacterial Endocarditis on the Right Ventricular Wall Opposite a Ventricular Septum Defect, Am. J. M. Sc. 202:207, 1941.

28. Clarke, J. J.: A Case of Ulcerative Endocarditis Associated With Stenosis of the Conus Arteriosus and Affecting Chiefly the Pulmonary Valve, With Ulceration of the Main Pulmonary Artery, Tr. Path. Soc. London 44:29, 1893 .

29. Cautley, E.: A Case of Pulmonary Regurgitation, Lancet 1:223, 1902.

30. Bosc: Endocardite pulmonaire aigué avec rétrécissement ayant simulé la tuberculose pulmonaire, Bull. soc. pédiat. de Paris 6:299, 1904.

31. Billings, F.: Chronic Infectious Endocarditis, Arch. Int. Med. 4:409, 1909.

32. Whipham, T. R.: A Heart Showing an Infective Polypoid Thrombus in the Pulmonary Artery and Extending Into the Right Ventricle and Mistaken for Patent Ductus Arteriosus, Proc. Roy. Soc. Med. (Children's Section) 4:199, 1911.

33. Trevor, R. S.: A Case of Multiple Mycotic Aneurysms of the Branches of the Pulmonary Artery Within the Lung, Proc. Roy. Soc. Med. (Path. Sect.) 5:155, 1912.

34. Gallavardin, L., and Josserand, A.: De l'absence de signes stethoscopiques dans une endocardite infectieuse de l'artère pulmonaire, Lyon méd. 138:690, 1926.

35. Bishop, L. F., Bishop, L. F., Jr., and Wallace, S. C.: Pulmonary Stenosis With Bacterial Endocarditis in an Adult, Am. Heart J. 5:238, 1929-1930.

36. Holzmann, M.: Ueber Septische Endokarditis der Pulmonalklappen, Ztschr. f. klin. Med. $115: 209,1930$.

37. Brandes, W. W.: Two Cases of Malignant Ulcerative Endocarditis of the Pulmonary Valve, Chicago Path. Soc. Tr. $13: 217,1930$.

38. Grayzel, D. M.: Pulmonic Endocarditis: A Clinical and Pathological Report of Three Cases, Yale J. Biol. \& Med. 7:515, 1935.

39. Moxon, W.: Case of Ulcerative Endocarditis of Right Heart, With Sloughing of Lungs, etc., Tr. Path. Soc. London 21:107, 1870.

40. Luzet and Ettlinger: Etude sur l'endocardite puerpérale droit et sur ses pulmonaires subaigues, Arch. Gen. de méd. 1:54, 1891.

41. Oerting, H.: Subacute Bacterial Endocarditis Involving the Tricuspid Valve Only, Minnesota Med. 14:82, 1931.

42. Osler, W., Luzet aud Ettlinger: Chronic Infectious Endocarditis, Quart. J. Med. 2:219, 1908-1909. 